\title{
EVOLUCIÓ I EXPRESSIÓ DE LA SEXUALITAT MEDIEVAL ${ }^{1}$
}

\author{
Flocel SABATE \\ Universitat de Lleida
}

\begin{abstract}
SUMARI
1. El marc de relació i de contacte entre sexes.- 2 . Els tractes sexuals incorrectes, inacceptables o contranaturals.- 3 . Les vies de la imaginació.
\end{abstract}

L'edat mitjana és un llarg trajecte ple de segles en constant evolució, a través dels quals l'ésser humà condiciona i amotlla el seu existir als diferents estímuls, conviccions i creences que configuren la mentalitat comuna. Així, la vivència sexual es modifica amb cada passa donada, tan responent a les necessitats concretes d'aquells homes $i$ dones com, alhora, perfilant uns conceptes $i$ unes actituds que, en molts casos, el temps ha perllongat més enllà del període medieval. En apropar-se, doncs, a la sexualitat medieval, encara que només sigui amb el cop d'ull contingut en un discurs breu, cal ambicionar no sols conèixer millor uns congèneres cada vegada més allunyats pel pas del temps sinó, sobretot, copsar una part de l'estrat que ha configurat les nostres arrels en aspectes, sovint, prou sentits i íntims.

1 Text íntegre de la conferència pronunciada a l'Institut Nacional d'Educació Física de Catalunya (INEFC) a Lleida el 21 d'abril de 1993. Les cites arxivístiques es limiten als exemples concrets inclosos a la conferència. En són emprades provinents dels arxius següents: ACA, Arxiu de la Corona d'Aragó; ACB, Arxiu Capitular de Barcelona; ADM, Archivo Ducal de Medinaceli; ADPO, Archives Départementales des Pyrénées-Orientales; AHCB, Arxiu Històric de la Ciutat de Barcelona; AHCG. Arxiu Històric de la Ciutat de Girona; AHMV, Arxiu Històric Municipal de Vic; AHTe, Arxiu Històric de Terrassa; APL, Arxiu de la Paeria de Lleida; AVV, Arxiu del Veguer de Vic; BNM, Biblioteca Nacional (Madrid). Respecte a les citacions bibliografiques, s'ha seguit el mateix criteri d'incloure-hi tan sols les referents a esments concrets. La bibliografia bàsica sobre el tema, en canvi, és indicada a: Flocel SABATE, Historia de la sexualitat medieval (en premsa). 


\section{El marC de RELACiÓ I de CONTACTE ENTRE SEXES}

Hom parteix de la constatació que viure en societat comporta l'obligada convivència d'uns éssers humans fisiològicament distingibles en dos gèneres, la qual cosa permet organitzar la col-lectivitat per mitjà d'atorgar a cadascun unes funcions determinades, les quals en alguns casos coincideixen per a ambdós, però en la majoria s'exclouen.

Al llarg de tot el període medieval, la dona sempre ha tingut com a propi l'espai domèstic, la qual cosa li confereix una significativa posició en la conservació, el manteniment i la perllongació del grup familiar i social on s'insereix, partint d'assumir com a pròpies les funcions reproductores, d'administració de la llar i d'enllaç amb d'altres llinatges mitjançant l'intercanvi matrimonial. Aquesta funcionalitat aboca facilment la dona als aspectes menys vistosos de la societat $i$, de fet, tot i la transcendència i la dedicació inherents, mai no sol rebre un reconeixement per aquestes activitats. L'home, en canvi, adopta com a propis els aspectes més externs i coincidents amb el govern polític $i$ econòmic.

Adaptat aquest plantejament a les diferents circumstàncies $i$ sense ser mai clarament qüestionat, l'evolució social acaba de perfilar el lloc corresponent a cada sexe, dibuixant uns canvis de posició que afecten, sobretot, la dona. Els primers segles medievals, els de confluència de la tradició romana i l'aportació germànica sobre el gresol cristià, per una banda justifiquen el lloc secundari atorgat a la Feminitat, vista amb una certa malfiança expressada per alguns Pares de l'Església tot sumant arguments clàssics -neoplatònics i estoics-i paulins. Altrament, però, l'acceptació social de la dona millora amb el contacte de les diferents civilitzacions, imprimint un reconeixement creixent ben clar des del segle $\mathrm{v}$ i reflectit en una millora legislativa. Un cert estancament en la seva valoració, al segle IX, prepara, de fet, una important presència en les centúries de l'esclat feudal. Els segles $\mathrm{X}$ i XI palesen, a tot l'Occident cristià, una gran equiparació de l'home i la dona pel que fa a l'apropiació de la propietat, a les diferents actuacions jurídiques, a les intervencions econòmiques $o$, fins $i$ tot, a l'accés a llocs de decisió administrativa i política de la societat, amb un dret privat que sol reflectir l'absència de discriminació per raó de sexe en aspectes prou determinants com les herències. Amb tot, el reconeixement en esferes administratives i de govern sol rebre'l la dona no tant per ella mateixa com de manera indirecta, sovint extraient importants conseqüències dels casaments ${ }^{2}$.

2 Es prou indicatiu el cas de Galícia: Carlos Baliñas Pérez "Domina": Condición femenina e pader público na Galicia altomedieval (sćculos vIII a IX), "Grial. Revista Galega de Cultura", XXVI-99 (1988), p. 81. 
La línia de valoració de la Feminitat, mantinguda durant el segle XI per definicions i lloances atentes a les qualitats tant físiques com morals de dones concretes, es materialitza al segle XII amb l'esclat de l'amor cortès, concepció literària però, alhora, reflex d'una mentalitat en la qual la puresa del sentiment d'amor dóna la pauta del que està bé i on l'home, com a enamorat, depèn de la decisió de la dona en el rebuig o en l'acceptació, física i espiritual, de l'amor.

Aquest recorregut no ha posat mai en discussió la ubicació de la dona en els àmbits domèstics, en els quals continua desenvolupant les seves funcions sustentadores de la família i del llinatge. Així, la dona dels trobadors i de l'amor cortès pot escollir o rebutjar l'amant, però no pas el marit. En l'elecció d'aquest, tot i ser sovint escoltada la seva paraula, aquesta ha d'entrar en joc amb els interessos generals existents.

Els canvis socials que comencen a percebre's en diferents llocs d'Europa durant els segles XI i XII, tot constatant l'auge dels sectors econòmics secundari i terciari i el creixement de la vida urbana, continuen palesant l'equiparació entre ambdós sexes. En aquests moments, les dones són presents pràcticament en tots els oficis, al marge de l'ocupació pròpia del marit. Destaquen, sobretot, en les diferents activitats tèxtils i en l'elaboració de productes alimentaris, situant-se en tot l'arc social laboral, amb teixidores de seda molt explotades, tant al nord italià com a Flandes i, a l'extrem contrari, amb empresàries com les angleses, que hereten amb tots els drets els establiments llaners dels marits. Igualment, les dones formen part de les primeres organitzacions laborals, sobretot a les ciutats alemanyes. En el mateix context, el camí vers el govern propi de les emergents urbs també compta amb el capital femení, important en molts episodis del moviment comunal i representatiu en diferents organismes de govern local en els països centreuropeus.

Ara bé, la mateixa dinàmica expansiva imposa, tant en l'afermament dels llinatges feudals com en la consolidació dels grups burgesos urbans, la necessitat de preservar unit, ferm i emprenedor cada patrimoni, entès sempre com una suma de drets $i$ propietats que permeten enlairar i mantenir el propi grup dins de les esferes de poder econòmic i polític. Així, tant des de la feudalitat com des del món urbà, s'avança cap a una agnació on el gruix patrimonial serà preservat mitjançant la transmissió pràcticament intacta en el primogènit masculí. L'accés de la dona al patrimoni, per tant, resta estroncat, la qual cosa es reflecteix immediatament en la seva acceptació: fins al segle XII, en el matrimoni, el marit ha d'aportar un important dot, però, a partir d'aquesta centúria, l'únic important és el dot que el pare de la núvia lliura a l'espòs. Això sol palesa i reforça, alhora, la convicció que la dona és una càrrega econòmica, a compte o del pare o del marit.

De fet, el triomf de la feudalitat, amb els lligams de fidelitat establerts 
dins de l'estament militar i amb el recurs, si cal, de la pressió i l'extorsió armada per a prosseguir sumant drets i propietats, permet situar l'accent del poder en el sector social d'on la dona ha estat absent durant tot el període medieval. A la vegada, el reforçament de la unitat familiar com a cèl.lula bàsica de la societat, mitjançant la imposició entre els segles X i xIl del matrimoni conjugal indissoluble i estable, facilita la visió de la unitat familiar identificada en el seu cap, en el context del patrilinealisme. Coetàniament, la dona perd evident pes en l'Església, tant de manera indirecta, per la major exigència en el celibat dels clergues des del segle XI, com pels canvis imposats en els patronatges, l'abolició dels monestirs dobles i la decadència dels cenobis femenins. Els puixants nous ordes monàstics poden emprendre reformes sense comptar pràcticament amb l'element femení, el qual, significativament, sí que té molt pes en els moviments herètics del segle XII.

Des de mitjan segle XIII és ben reblat el desplaçament del sexe femení dins la societat. Es limita la seva participació en les organitzacions laborals $i$ en les municipals. De les sorgides a partir d'ara ni tan sols no en forma part, com és clar a la Península Ibèrica. La mesura respon a una convicció ben estesa: com es diu al París del final del segle XIII, és impensable que una dona ascendeixi en el món laboral, perquè si esdevingués mestra hauria d'ensenyar a homes, la qual cosa seria tan inacceptable com que un adult es sotmetés al mestratge d'un infant.

En la mateixa línia, els nous Estudis Generals no hi admeten la presència de la dona, que així és exclosa de la formació intel-lectual i dels oficis inherents, de forta implantació social, com l'advocacia, el notariat o l'ensenyament. Aquesta exclusió del saber permet que hom li discuteixi, fins i tot, la permanència en àmbits tradicionalment molt femenins, com la medicina.

L'adopció del dret romà permet emparar la nova situació, i els avantatges ara introduits en benefici de l'esposa, com el senatconsult vel.leiá ${ }^{3}$, normalment es poden matisar $i$, en qualsevol cas, rauen en la protecció que es considera adient per a l'eisser femení per raó de la seva inferioritat. Precisament, ara es reprèn amb fermesa el discurs intel-lectual que insisteix en la feblesa i la inferioritat física i moral de la dona. Tot ho confirma: l'exegesi bíblica recorda que el pecat començà per ella, la tradició intel.lectual ha alertat sempre dels seus instints, l'anàlisi dels diferents autors ha evidenciat que l'esperit de la dona pot explicar-se des del vicis que la caracteritzen -luxúria, cobdícia i, si de cas, també golafreria ${ }^{4}$ i, fins i tot, la

${ }^{3}$ Jesús LAUINDE ABADIA, La recepción española del senadoconsulto Velleyano, "Anuario de Historia del Derecho Español", XLI (1971), pp. 351-352.

${ }^{4}$ Són vicis que es complementen perniciosament, destacant-hi sempre la relació de la dona amb els pecats de la carn, com és molt clar en la consideració de la golafreria, perquè "entre gourmandise et luxure, il n'y a qu'un pas" (Allen J. Grieco, Tables et tableaux, London-Paris, 1992, p. 9). 
nova ciència mèdica corrobora que la luxúria forma part de l'ésser femení per la presència, en la dona, de l'humor líquid, impregnat de la humitat característica de la luxúria. Durant la resta de la baixa edat mitjana, la dona, atrapada en aquestes consideracions, restarà en un lloc molt secundari, malgrat alguns casos on conserva importants capacitats laborals. De fet, la degradació en la imatge i valoració de la dona adoba el terreny envers els temors' que portaran a fenòmens com l'obsessió per les bruixes, esclatada just després del període medieval ${ }^{6}$.

L'evolució de les diferents posicions de cada un dels dos sexes a la societat s'ha realitzat coexistint sempre amb un contacte físic mutu. Aquesta relació corporal entre l'home i la dona tothora ha estat justificada en el deure de la procreació, tal i com constantment ho han dictaminat les autoritats $i$ els teòlegs de l'Església. El marc i la manera en què s'ha materialitzat aquest obligat contacte també ha anat evolucionant amb el temps, perfilant unes formes diferents segons es situii a l'alta o a la baixa edat mitjana.

A l'alta edat mitjana el cos és vist amb temença i malfiança. El cos, identificat amb la matèria contrària a l'esperit, és contraposat a aquest tant pel manteniment, a través de la Patrística, d'una influència del neoplatonisme i de les petges d'haver estat alguns autors a prop del maniqueisme, com per la convivència amb un estoicisme, ben estès dins la societat baiximperial, que redueix la relació sexual a l'austeritat i la concepció. Aquest plantejament es combinarà amb la preferència dels durs models veterotestamentaris, com ho imposen els monjos irlandesos $i$ anglesos que estendran els seus ideals per l'Europa central.

Coherentment, el millor estat és la virginitat i la continència sexual. A vegades fins $i$ tot és forçada, com en els casos de castrament imposats sobre si mateix o, en altres ocasions, realitzats per la mare tot desitjant que el fill petit segueixi la vida consagrada, com es fa sobretot en els primers segles a Bizanci, on la pràctica no estranya gaire perquè era igualment present en algunes expressions mistèriques pròpies del període baix-imperial. El matrimoni és per als qui no puguin assolir aquest estat de perfecció i sempre ha de ser entès $i$ justificat pel deure de la procreació. El model matrimonial el configuren els esposos que, un cop acomplert el deure de procrear, entren per separat en monestirs per viure el lliurament a l'esperit, com ho remembra l'hagiografia referint-se a casos ben presents a Bizanci tant el segle $\mathrm{V}$ com el IX.

La impuresa pròpia del tracte sexual justifica que els esposos hagin de limitar al màxim el seu contacte i que l'efectuïn amb la menor passió carnal possible. El millor seria fer-ho com diuen que s'acoblen els elefants: el mas-

5 Jean Delumeau, La peur en Occident, Paris, 1978, pp. 411-412.

6 Norman CoHN, Los demonios familiares de Europa, Madrid, 1987, pp. 137 i ss. 
cle gira el cap com avergonyit per no veure què fa. Igualment, atès que tot contacte sexual comporta apropar-se a la impuresa, és comprensible que sigui limitat l'accés a l'Eucaristia als esposos que han mantingut relacions sexuals en un període que s'imposa entre una o tres nits, de la mateixa manera que cal exigir que l'abstinència sexual sigui tan seguida com l'alimentària respecte a la carn, a la vigília dels dies litúrgicament assenyalats. La noció d'impuresa, de fet, provoca una malfiança permanent respecte al propi sentiment i desig i, també, respecte a la mateixa fisiologia: cal discutir la noció de culpa que pot haver-hi en les pol-lucions nocturnes, sobretot a través del somni que potser les ha acompanyades, i cal limitar l'accés als llocs $\mathrm{i}$ cerimònies sagrades a dones amb el cos ostensiblement impur sota els efectes menstruals.

El conjunt d'aquestes directrius defineix el raonament $\mathrm{i}$ el discurs imperant, però, malgrat el creixent pes social de l'Església, no anul.la expressions menys contingudes, que traspuen a través de tot un conjunt d'actituds desagradables als predicadors: jocs verbals al.lusius, balls, insinuacions en els banys compartits, apropaments físics de diferent grau i contactes sexuals que ignoren les normes establertes en tots els ordres, tal i com han de castigar els penitencials. L'oposició latent en part de la població sura de manera clara en aspectes com l'existència de fórmules adreçades a provocar l'atracció amorosa o, directament, a augmentar el desig sexual mitjançant preparats d'herbes o recursos homeopàtics.

A la vegada, en arribar als segles centrals de l'edat mitjana, la mateixa societat del segle XI que contempla el càstig del cos amb dejunis i penitències $^{7}$, aprecia actituds lúdiques dels joves nobles ${ }^{8}$ on el desig sexual cerca expressions no contingudes. L'esclat de l'amor cortès en el segle XII comporta la reivindicació d'un sentiment apassionat que desitja la materialització en la fusió dels dos amants sense atendre cap ordenament, ni tan sols el matrimonial ${ }^{9}$, raonant, si de cas, que l'amor ho justifica tot: la dona que es deixa portar per l'amor, malgrat infringir les normes morals establertes, en paraules del trobador Bertran de Born, és monda de totz sos pechatz ${ }^{10}$.

De fet, la baixa edat mitjana perd la malfiança al cos. Les noves aglomeracions d'estudiants joves subsegüents a la creació dels Estudis Generals

7 Michel SoT, Mépris du monde et nesistance des corps aux Xle et XIle siècles, "Medievales", 8 (1985), pp. 6-17.

8 Georges DUBY, Los "jovenes" en la saciedad aristocrática de la Francia del noroeste en el siglo XII, "Hombres y estructuras de la Edad Media", Barcelona, 1989, pp. 132-147.

9 Erich KolHer, Sens et fonctions du terme "jeunesse" dans la poésie des troubadours, "Mélanges offerts à René Crozet à l'occasion de son soixante-dixième anniversaire", I, Poitiers, 1966, pp. 569-583.

${ }^{10}$ Gerard GouIRAN, L'amour et la guerre. L'oesure de Bertran de Born, Aix-en-Provence, 1985 , p. 125. 
fan ostentació d'uns plantejaments morals ben desinhibits, reivindicant per a tothom l'accés a la pràctica sexual ${ }^{11}$. Des del món intel-lectual, el segle XIII Sant Tomàs d'Aquino haurà d'insistir contra actituds de malfiança respecte al cos encara presents en autors de la centúria precedent. El coneixement de la medicina àrab, l'assumpció de la física aristotèlica i les directrius filosòfiques $\mathrm{i}$ teològiques sorgides tant del realisme escolàstic com, després, del nominalisme, propicien l'acceptació de l'activitat sexual com una funció normal, bàsica i necessària per al funcionament de la societat i per al desenvolupament humà, per bé que només és, sempre i exclusivament, justificada en el deure de procrear.

Això obliga no tant a rebutjar el cos com a vetllar per al seu correcte ús i comportament. Deriva d'aquest raonament una veritable obsessió per a l'adient conducció de l'esperma. Aquest és generat en el cos de l'home per a germinar en el cos de la dona. Sols poden ser acceptats com a vàlids i correctes, per tant, els comportaments sexuals que garanteixin aquest objectiu, és a dir, la relació heterosexual amb penetració vaginal. La nova visió de l'anatomia humana, de caire aristotèlic, revalida aquesta concepció, perquè hom descarta que la generació es formuli per la suma de l'esperma masculí i el femení a l'úter, com es creia fins aleshores tot seguint Galè, i ara, després de rebutjar l'existència d'un esperma femení, es pot explicar la generació amb un esquema hilemòrfic.

Aquesta interpretació teleològica de la relació sexual, adoptada pel deure natural a la procreació, justificada en el raonament teològic i corroborada des de les recents aportacions mèdiques, deslliura el cos de malfiances excessives en el tracte sexual, per bé que, en contrapartida, accentua la finalitat del contacte carnal, de tal manera que tot el discurs relatiu a l'activitat sexual serà interpretat sempre des de la teleologia que en justifica la raó de ser. L'objectiu propi del contacte condiciona la seva existència, la seva finalitat i la manera d'apropar-s'hi. Per això, garantit aquest aspecte, el manteniment de la noció virginal com a estat més perfecte i el discurs entorn dels perills de la luxúria es poden compaginar amb una gran tolerància respecte al comportament sexual $\mathrm{i}$ hom pot referir-se a la unió dels cossos com a felix conjunctio i tractar obertament sobre les maneres de perllongar el plaer sexual.

De tota manera, ultra encertar el sentit del tracte sexual i condicionar-ne les formes i maneres d'accés a partir d'aquest coneixement, cal encarrilar-lo amb correcció dins d'un marc social adequat. Aquest és l'espai del matrimoni. La noció matrimonial també és fruit d'una evolució que la constitueix, cap al segle XI, en la cèl.lula social bàsica, nascuda del deure de procrear $\mathrm{i}$ establerta de manera indissoluble per un contracte

11 Jacques LE Gopr, Los intelectuales en la Edad Media, Madrid, 1985, pp. 51-52. 
civil i religiós reforçat sacramentalment, amb els esposos units per l'estima comuna.

Aquesta noció s'ha obert pas de la mà de l'Església després de superar les tradicions contràries, tant germànica com romana, i la interessada oposició dels grups dirigents alt-medievals, com és clar a la França merovíngia $i$ en els segles posteriors. De fet, el divorci per mutu acord a les zones de tradició romana es continua aplicant al segle VIII i no decau fins al següent. Igualment, s'havia perllongat la noció de repudi germànic, mantinguda interessadament després pels grups dirigents, els quals, per als intercanvis d'aliances, es senten necessitats d'una noció de matrimoni que permeti el repudi segons la conjuntura política. En realitat, la mateixa noció del matrimoni monògam ha d'obrir-se pas entre la pervivència d'una mena de concubinatge en la població benestant de tradició romana a partir de l'esclavatge $i$, pel que fa als germànics, entre una noció matrimonial àmplia pel fet de combinar alhora dos tipus d'unió, afegint-hi encara el recurs a les esclaves. Igualment, la poligínia té un ressò cabdal entre els pobles escandinaus, els quals assoleixen una forta cohesió interna mitjançant el joc d'intercanvi d'esposes que permet un sistema matrimonial que Occident identifica tan clarament amb la poligàmia que parla d'aquesta com el matrimoni more danico.

L'Església aprofita el pes exercit en la societat carolíngia per anar assolint que, entre els segles IX i X, la legislació vagi assumint les seves directrius en matèria matrimonial. Coetàniament, la mateixa Església culmina la discussió interna tant sobre el sentit del matrimoni -civil o religióscom respecte a la capacitat amb què hi pot intervenir. En realitat, la implantació del model eclesiàstic comportarà enfrontaments greus amb la noblesa. Es molt coneguda la tibantor amb Lotari II, el qual, en pretendre, a mitjan segle IX, repudiar l'esposa estèril i substituir-la per la concubina amb qui ja tenia un fill, rep la confirmació del sínode de Coblenza, però immediatament haurà de recular per la pressió de l'arquebisbe Hincmar de Reims i del papa Nicolau I, que es fan refermar pel sínode laterà del 863.

La historiografia ha valorat molt aquesta implantació del model eclesiàstic matrimonial entre els nobles, tot superant el model d'aquests, que vol mantenir el repudi $i$ ignorar la noció àmplia d'incest, amb la convicció que d'una altra manera perillaria l'estructura vigent d'intercanvi d'aliances entre els poders baronials. En realitat, el model eclesiàstic no es considera ben introduit fins al tombant del segle XI al XII ${ }^{12}$. A la vegada, existiren també dificultats, cronològicament anteriors, pel fet d'imposar el mateix model entre els grups socials inferiors, sobretot per haver de conjuminar

12 Georges Duby, El matrimonio en la sociedad de la Alta Edad Media, "El amor en la Edad Media y otros ensayos", Madrid, 1990, pp. 26-31. 
aquest ideal conjugal amb concepcions familiars molt més àmplies $\mathrm{i}$ fins $\mathrm{i}$ tot més tolerants. El mateix pes de la legislació i l'existència d'un gruix menor d'interessos entre aquest grup social en facilitarà, pròpiament, l'acceptació. El canvi comporta, en definitiva, un major control social, una més forta presència de l'Església i la limitació d'unions inestables i considerades incestuoses $o$ irregulars.

Es mantindran, però, en els nivells superiors de la societat, trencaments matrimonials. Les raons al.legades - cada cop més l'existència d'un grau d'incest- solen amagar tibantors molt fortes tant personals, entre els esposos, com en el joc d'interessos que, de fet, els ha menat al matrimoni. Per això, les disputes entre esposos monarques poden comportar veritables enrenous polítics, com en el cas d'Alfons I d'Aragó i Urraca de CastellaLleó, els quals, units en matrimoni el 1109 i desavinguts immediatament, dos anys després s'enfrontaven bèl-licament cadascun amb el seu exèrcit. En el mateix segle, l'anul-lació del matrimoni entre Leonor d'Aquitània i el rei francés Lluís VII, aprovada pel concili de Beaugency el 1152, facilitarà tot un replantejament geo-estratègic de la zona en benefici de l'Anglaterra Plantagenet. Al llarg de l'edat mitjana persistiran les separacions entre monarques: el segle XIII, per exemple, Alfons X de Castella, després de legislar en les seves Partides la indisolubilitat del matrimoni, tractarà d'aconseguir el repudi de la seva esposa, Violant d'Aragó. Però, a mesura que es penetra en la baixa edat mitjana, no es plantegen tensions com les viscudes el segle XII, perquè la dona ha anat assumint, també a les altes esferes, un espai més secundari amb menys capacitat pròpia de poder.

El segle XI, les filles del Cid anul.len amb facilitat, segons el famós poema, la unió amb els seus esposos perquè ells les han maltractades ominosament ${ }^{13}$. En realitat, en els diversos problemes, ultra les consideracions polítiques, hi bateguen, en tots els diferents grups socials, les tibantors i els enfrontaments entre els esposos, la qual cosa deriva, en gran part, del desconeixement entre els dos contraents en establir-se l'enllaç. La funció del matrimoni com a lligam entre llinatges i grups familiars, tant en l'àmbit feudal com entre la burgesia urbana, justifica que les unions es facin al marge dels sentiments. Sovint, ambdós contraents són practicament adolescents, tot i que a la baixa edat mitjana és usual que ella sigui entre 10 i 15 anys menor que ell, un home madur que cerca una esposa jove per a engendrar fills sans que mantinguin els interessos familiars. La necessitat del dot -cap matrimoni no es pot realitzar sense el dot de la dona, com ja ho recull el Decret de Gracià a mitjan segle XII- es sublima i un bon dot és símbol d'un casament honorable. Precisament, un acte pietós de la baixa edat mit-

13 Cantar del Mro Cid, 129; 152 (Cantar del Mro Cid, Luís GuARner, ed., Barcelona, 1970, pp. 279, 347) 
jana, present en molts testaments, és llegar diners per a dotar noies pobres ${ }^{14}$, activitat assumida en alguns casos pels municipis en virtut de les solidaritats municipals $i$ esdevinguda, en indrets concrets com a Florència, una manera d'invertir tot remenant així els capitals que restaven immobilitzats per a preparar els bons dots de les filles ${ }^{15}$.

En la unió matrimonial, la necessitat de preservar el propi llinatge i la noció superior de l'home imposen el concepte de virginitat sobre la dona. L'exigència, ignorada en sentit invers, contribueix, de fet, a accentuar el domini de l'home sobre la dona, en tant que ell adquireix la capacitat d'exigir en ella unes condicions físiques mitjançant les quals controla el seu cos, alhora que se'n garanteix la possessió.

Entre els dos contraents s'entén que hi ha de regnar un sentiment d'estima, basat en la caritat cristiana, com en deia Innocenci I al segle v. Aquesta dilectio permet compartir les càrregues del matrimoni i procrear els fills $i$ és aliena a l'apassionament sensual $i$ irracional anomenat amor, el qual deriva de la cupiditas com a fruit de la libido que sol caracteritzar la dona tot arrossegant-hi l'home. Precisament, l'amor cortès exalta, en canvi, en el segle XII, aquest sentiment, fins a apropar-lo al mateix amor diví, la qual cosa, però, ha de fer-se fora i contra el matrimoni: l'amor cortès ha de ser adulterí per definició.

Tot i la vulgarització i banalització del terme amor de cara a la baixa edat mitjana, conjuntar ambdós conceptes - l'amor i el matrimoni- no serà usual i fins i tot semblaria una cosa ben rara, com ho indica Bernat Metge, el qual recull la compatibilització, en l'home, de viure la passió amorosa per l'amant $i$, alhora, d'estimar la pròpia muller aitant com los marits acostumen $^{16}$. Durant la baixa edat mitjana es raona que un dels avantatges de casar la noia ben jove era tenir-ho fet abans que no s'enamorés. De tota manera, no deixa de ser possible, per bé que rar, enamorar-se del propi cònjuge. Hi ha exemples d'unions fermes com Eginard en el segle IX, que es deprimí ostensiblement a la mort de la seva muller, tot expressant que compartien una unió física i espiritual. De manera més anònima, Serena de Tous era una barcelonina de mitjan segle XIV capaç d'escriure cartes al seu marit llunyà tot evocant la bona amor qui és entre vós e mi, que serà, si Déus bo vol, de la mia vida ${ }^{17}$.El segle $\mathrm{xV}$, aprofundint en la mateixa línia, Christine de

14 Maria Teresa VINYOLEs, Ajudes a donzelles pobres a maridar, "La pobreza y la asistencia a los pobres en la Cataluña medieval", I, Barcelona, 1980, pp. 295-362.

is Milagros RiverA, La legislación del "Monte dell doti" en el quatrocento florentino, "Actas de las II Jornadas de Investigación Interdisciplinaria. Las mujeres medievales y su ámbito jurídico", Madrid, 1983., pp. 159-173.

${ }^{16}$ Bernat MeTGE, Lo somni, Barcelona, 1980, pp. 94-95.

17 ACB, Cisme d'Occident, doc. 1205 [transcrit a Teresa Maria VinYoles, Cartes d'una catalana del segle XIV al sex marit, "Estudis Universitaris Catalans", XXVI (1984), p. 406]. 
Pizanne expressa el desig que el marit sigui bo, amorós, sol-lícit i comprensiu, ideal per a compartir tota la vida ${ }^{18}$.

En realitat, conviure amb la parella no era tan facil. Tot i que cadascun tenia uns rols socials ben imposats - la dona abocada al món domèstic i ell a les tasques més reconegudes- existia un marge per on la convivència s'esquerdava en haver-se imposat sense comptar amb els sentiments. Al segle XIV, el vescomte d'Illa assassinà la seva esposa, ell mateix ${ }^{19}$. Això no és pas un fet inusitat: el $25 \%$ de les dones assassinades a Catalunya en aquest segle han estat víctimes del propi marit, de la mateixa manera que el $15 \%$ de les vegades que la dona apareix en els tribunals com a víctima, es deu a haver estat objecte dels maltractaments físics de l'espòs ${ }^{20}$.

Colpejar la pròpia muller és un dret reconegut en alguns països europeus, com a Anglaterra ${ }^{21}$. A Catalunya, en canvi, les esposes poden denunciar la situació a l'autoritat judicial ordinària. La gran extensió del fenomen impulsa a tractar de prevenir aquesta violència marital. La mesura es podrà fer mitjançant les seguretats. Aquestes consistien en un manament pel qual hom contreia davant de l'autoritat ordinària una obligació de qualsevol mena, tant econòmica com de comportament, sotmetent-se a una multa en cas d'incompliment ${ }^{22}$. Aplicat a la violència marital, es tracta de comprometre el marit a no tornar a colpejar l'esposa. La mesura és més efectiva que no pas els compromisos similars contrets particularment davant de notari, però no estronca la línia seguida: la majoria dels uxoricidis són, alhora, trencaments de manaments.

A la vegada, el caire imposat del matrimoni fa cercar vies de fugida. A Bizanci, no és infreqüent que l'esposa abandoni el marit per a refugiar-se en un monestir femení, del qual l'espòs sols la podrà treure en convèncer-la que ja no serà violent. Aquest recurs també es farà present a l'Europa feudal, tot i que esdevé més freqüent entrar en un monestir com a via per a defugir la realització del matrimoni. De manera molt més usual, per part dels afectats es pretén poder imposar la unió desitjada, tot forçant el grup familiar a acceptar la situació mitjançant el casament. Amb aquesta intenció, al llarg de tota l'edat mitjana es practicarà el rapte de la dona per a forçar la unió matrimonial. Les legislacions germàniques s'hi mostren dures, per bé que encara el segle XIII Jaume I haurà de legislar contra els

${ }^{18}$ Christine de Pizan, La ciutat de les dames, Barcelona, 1990, pp. 141-142.

19 ADPO 1B-209, sense numerar.

20 Flocel SAваTE, Femmes et violence a la Catalogne du XIVìme siecle "Annales du Midi» (en premsa).

21 Margaret Wade LABARge, La mujer en la Edad Media, Madrid, 1988, pp. 258-259.

22 Flocel SABATE, El veguer a Catalunya. Anàlisi del funcionament de la jurisdicció reial en el segle XIV, Universitat de Barcelona, 1993, tesi doctoral inedita, pp. 589-590.

${ }^{23}$ AHCB C-V, caixa 1 , full solt. 
raptors i contra les donzelles que es deixen raptar ${ }^{23}$. Malgrat la condemna generalitzada, al segle XIV, la sisena part dels raptes efectuats a Catalunya conclouen en matrimoni. La mateixa mesura és emprada per dones casades, tot emparant-se legalment sota l'aixopluc del rapte, quan el que estan fent és fugir amb l'amant tot pretenent no tornar ${ }^{24}$. Les separacions de fet són relativament freqüents, sobretot en marits que abandonen esposes encara joves ${ }^{25}$, tot $\mathrm{i}$ no ser gaire ben vistes, sobretot si comporten adulteri ${ }^{26}$. A la inversa, l'abandonament per part de la muller és força menys freqüent, i es sol relacionar encara més amb l'adulteri. Cada cop més, davant d'aquests casos, els governs locals, valorant el trastorn social, obliguen l'esposa a tornar, per bé que a vegades la mesura és inviable perquè la fugitiva ha canviat de jurisdicci6 ${ }^{27}$, prudència que sol ser molt comuna en aquests casos.

Un altre recurs habitual entre solters, per a forçar el reconeixement d'una unió desitjada, és plantejar els fets consumats mitjançant un casament secret. Es ben freqüent tot i les condemnes, que passen pel desheretament $^{28}$. Des de la imposició del matrimoni segons la concepció sacramental cristiana, és preceptiu que un clergue presideixi la unió. Però, teològicament, ell sols pot fer de testimoni del casament, el qual, en realitat, és prou vàlid solament amb la consumació per part dels contraents. Per tant, un matrimoni no solemnitzat pot ser titllat d'incorrecte, però teològicament la unió és real i legítima. Per raons diverses, de matrimonis secrets, n'hi ha molts $\mathrm{i}$ als diferents nivells. Es present en els estrats més baixos de la societat i també en els més alts: la reina Margarida de Prades, mort el seu espòs Martí I, per tal de no perdre la condició de reina vídua, es casà en secret amb el cavaller Joan de Vilaregut ${ }^{29}$.

En general, l'Església baix-medieval tracta de combatre els matrimonis secrets amb l'aplicació d'excomunió als contraents, just quan aquesta pena és prou banalitzada ${ }^{30}$. En els estrats inferiors de la societat, l'excomunió rebla l'escassa consideració atorgada als afectats ${ }^{31}$ i permet, entre la població, estendre automàticament la consideració d'excomunicat: de Joan de premsa).

${ }^{24}$ Flocel Sabaté, Femmes et violence à la Catalogne du XIVe siècle "Annales du Midi» (en

25 Isabelle CHАвот, "Sola, donna, non gir mai". Le solitudini femminili nel Tre-Quatrocento, "Memoria. Rivista di storia delle donne", 18 (1986), pp. 15-17.

26 APL. Secció Administració de Justicia. Procés de crims A-764, Fol. 27r.

27 Luís Rubio Garcî, Vida licenciosa en la Murcia bajomedieval, Murcia, 1991, p. 28.

28 AHCB C-V, caixa 1, sense numerar; AHCG XVIII Llibre Verd, fols. $72 \mathrm{r}-\mathrm{v}$, entre d'altres.

${ }^{29}$ Ferran Soldevila, Les dones en la nostra bistoria, Barcelona, 1966, p. 57.

30 Nora B. RAmos, La Iglesia a traves de las cortes castellana. Uso y abuso de la excomunión (ss XIII-XIV), "Cuadernos de Historia de España" LXIX (1987), pp. 102-103.

${ }^{31}$ AVV, Processos criminals, volum 1, plec 2, sense numerar. 
Montesquiu, un terrassenc del segle XIV poc reconegut socialment, hom deia que est excomunicatus quia interfuit in matrimoniis clandestinus ubi non era nec fuit capellanus ${ }^{32}$.

En realitat, casos com aquest són pròxims al concubinatge laic $i$, de fet, en diferents moments es dubtava, a la baixa edat mitjana, d'aplicar-hi l'una consideració o l'altra. Conviure de manera pública sense lligams de casament era, pròpiament, un concubinatge. Tot i ser molt estés, era progressivament mal vist, i a la baixa edat mitjana es tendeix cada cop més a identificar-ho com a propi dels estrats socials menys reconeguts.

De tota manera, l'existència ferma de totes aquestes formes no reflecteix sempre el triomf d'un sentiment amorós contra unes formes imposades. Consta que algunes unions no legitimades també responen a interessos.

$\mathrm{Hi}$ ha un progressiu rebuig d'aquestes expressions que escapen del marc matrimonial, però, a la vegada, es palesa una tolerància i comprensió. De fet, més que un combat entre sentiments i formes, les dificultats del matrimoni per a consolidar-se com a fórmula indiscutida reflecteixen l'existència d'uns requeriments socials que no poden ser encabits en el matrimoni tal com era concebut $\mathrm{i}$ imposat. En aquest sentit, és prou conegut el contracte de concubinatge establert entre Jaume I i Aurembiaix d'Urgell poc després del primer quart del segle XIII ${ }^{33}$, però també cal esmentar permisos reials concedits, encara que de manera escadussera, a favor d'alguns súbdits concrets per tal de poder mantenir legalment una concubina tot $\mathrm{i}$ ésser casats, com ho fa Joan I al final del segle $\mathrm{XIV}^{34}$.

Així el matrimoni, per una banda, es consolida com la cèl.lula bàsica de l'organització social, marc únic on correspon entendre la relació sexual, justificada per la procreació, la qual ha d'estar ordenada segons la pròpia identitat. Per altra banda, des del valor dels sentiments, des dels usos sexuals amb finalitat diferent a la definida, des de la topada d'interessos confrontats $\mathrm{i}$ des de formulacions diverses, hi ha unes altres actituds, formes i marcs de relació sexual, els quals, però, pel fet de sortir del marc corresponent, perfilaran una àmplia gamma d'actuacions incorrectes, inacceptables o, fins i tot, contranaturals.

$\mathrm{Al}$ mateix temps, entre les comunitats no cristianes presents a Occident -la jueva i, molt centrada en el sud europeu, la musulmana- també el matrimoni és el marc escollit per a la relació sexual, tot bastint un sistema patriarcal jeràrquic a favor del marit, en el qual l'espai propi de les dones resta igualment perfilat dins l'àmbit domèstic. La preocupació pel propi llinatge és constant, i la virginitat de la dona és altament valorada i exigida. Entre els

32 AHTe Processos, Caixa 2, 1333, fol. 7r.

33 Ferran Soldevila, Jaume I. Pere el Gran, Barcelona, 1985, p. 9.

34 ACA, Cancelleria, reg. 1877, fol. 152 r-v. 
musulmans la poligàmia resta per als senyors més poderosos, mentre que el poble corrent és, de fet, monògam. Ambdós pobles mantenen abstinències sexuals: els musulmans durant els dies -no pas les nits- del Ramadà i els jueus durant el dia del Yom Kippur, per bé que en cap d'aquests casos la penitència i purificació no comportin un greu discurs de rebuig del cos.

\section{ELS TRACTES SEXUALS INCORRECTES, INACCEPTABLES O CONTRANATURALS}

En primer lloc, el matrimoni, ha de mostrar-se endreçat en si mateix. La malfiança amb què l'alta edat mitjana contempla el cos es concentra en la moderació exigida als esposos, tant en l'expressió dels seus sentiments com en la materialització de l'acte sexual. La famosa expressió adulter est amator ardentior in suam uxorem adaptada, el segle III, per Sant Jerònim de l'escèptic Sext Empíric, és prou expressiva, i serà represa per tractadistes baix-medievals com Francesc d'Eiximenis. Sant Tomàs d'Aquino, en teoritzar sobre el matrimoni cristià, valora la convivència dels esposos com a via de perfecció cristiana, per bé que defineix aquesta col-laboració quotidiana com el fi secundari de la unió conjugal, mentre que la finalitat primària és la generació i cura dels fills ${ }^{35}$. Aquest deure imposa també limitacions en el tracte sexual: com ho adverteix Sant Vicenç Ferrer, mantenir relacions sexuals en període de lactància podria comportar un afebliment del lactant, per la qual cosa és recomanable estar-se'n mentre duri l'alletament. De tota manera, la freqüència d'embarassos -cada 18 o 21 mesos de mitjana ${ }^{36}$ indica que aquests consells, que recomanaven abstinències de fins a tres anys ${ }^{37}$, no eren, en realitat, gaire seguits.

Alhora, la interpretació del matrimoni en funció de la concepció obliga a establir el contacte sexual de manera que resti ben garantida la finalitat de la unió. Això mena a una situació dins de l'Església resumida amb un reeixit títol de Brundage: let me count the ways: canonist and theologians contemplate coital positions ${ }^{38}$. Certament, durant tota l'edat mitjana es considera que la postura normal de realitzar l'acte sexual és la penetració vaginal amb 472.

35 Antonio Royo MARTIN, Teologla de la perfecccion cristiana, Madrid, 1968, pp. 471-

36 Jean-Louis FLANDRIN, Un temps pour embrasser. Aux origines de la moral sexuale occidentale (VIe-XIe sièles), Paris, 1983, pp. 89-90; Christiane KLAPISH-ZUBER, La mujer y la familia, "El hombre medieval", Madrid, 1990, p. 301.

37 Xavier Renedo, De libidinosa amor los efectes, "L'Avenç", 123 (1989), p. 20.

38 James A. BRUNDAGE, Let me count the ways: canonist and theologians contemplate coital positions, "Journal of Medieval History", 10, (1984), p. 81. 
l'home bocaterrossa damunt de la dona en posició supina. Aquesta postura concorda tant amb la finalitat pròpia de la relació sexual, perquè garanteix la correcta conducció de l'esperma des del cos masculí a l'úter femení, com amb l'ordre de la natura, perquè corrobora que l'home és situat sobre la dona i la domina ${ }^{39}$. En canvi, la segona postura més practicada, per bé que a distància de la primera, l'anomenada a l'alta edat mitjana a tergo (també in terga) o, com consta al segle XI, more canino, consistent en una penetració vaginal des de darrera del cos femení, provoca malfiança ja que s'assembla massa a la forma de fer-ho la majoria dels animals irracionals. De tota manera, en garantir la conducció de l'esperma, no mereix una condemna forta. De fet, s'imposarà, en gran part i a nivell general, tant la posició dirigent de l'home en la relació sexual com l'assumpció del conducte vaginal. En aquest sentit, malgrat separar-se de l'única manera de realitzar l'acte sexual plenament avalat pels moralistes $\mathrm{i}$ tot $\mathrm{i}$ reflectir una clara influència del saber musulmà, el tractat del foder, redactat cap al segle XIV, descriu vint-i-quatre postures coitals diferents, les quals, però, sempre giren entorn de la penetració vaginal, sense contemplar altres expressions eròtiques ${ }^{40}$.

Una consideració molt diferent mereix la penetració anal, practicada entre esposos tant a l'alta com a la baixa edat mitjana, sovint adreçada directament a evitar la concepció. Per pròpia definició desvirtua la finalitat atorgada al sexe, a la vegada que la similitud amb les pràctiques homosexuals masculines la fa especialment rebutjable, sobretot a la baixa edat mitjana.

Així, existeixen maneres d'apropar-se a l'acoblament sexual tractant decididament d'evitar la concepció. Tot i que l'índex de natalitat era molt elevat, superior al $40 \%$. com correspon a les societats pre-industrials, les pràctiques contraceptives eren corrents, la qual cosa permet deduir un elevat nombre de contactes sexuals en cada parella. El recurs a la contracepció és contrari a la finalitat atorgada a la relació entre sexes, per la qual cosa sempre ha estat prohibit per l'Església medieval, amb poques i concretes excepcions. Aquestes directrius morals eren desoïdes en les famílies, sobretot per motius econòmics. En segon lloc, la contracepció també acull unes altres raons, centrades sobretot en no voler derivar cap a la procreació relacions mantingudes entre joves enamorats o contactes il.lícits per raons socials o ètnico-religioses. A l'alta edat mitjana, ultra el recurs al coitus interruptus $\mathrm{i}$ als amulets, eren ben freqüents diferents preparats d'herbes amb finalitats contraceptives, que calia ingerir, per via oral o vaginal, abans $o$ immediatament després del coit, segons els casos. També s'intentà aplicar una mena de diafragma per a retenir el semen. Es tracta d'uns mètodes

39 Jean Louis Flandrin, Le sexe et l'Occident. Evolution des attitudes et des comportements, Paris, 1984, p. 129.

40 BNM, manuscrito 3356, fols. 35 r-54 v. 
mantinguts bàsicament en mans femenines, coneixedores i transmissores de les fórmules. En canvi, a la baixa edat mitjana destaca sobretot la pràctica del coitus interruptus, molt més efectiu. Aquest predomini no sembla pas casual, ja que aquest mètode esdevé una tècnica masculina reiterada en les diferents societats pre-industrials on les unitats matrimonials es situen sota domini masculi ${ }^{41}$.

Una altra manera d'incomplir el deure de procrear és provocar l'avortament. El recurs a l'avortament es practica durant tota l'edat mitjana, continuant l'ús exercit al baix-imperi romà. Sempre, però, ha estat condemnat per l'Església i pel poder civil, entenent que s'hi estroncava la vida d'un ésser humà amb ànima pròpia. Malgrat això, els mateixos motius que s'apleguen per cercar mètodes contraceptius es reiteren en l'avortament per justificar-ne la pràctica durant tota l'Edat mitjana. Existien uns preparats, normalment d'ingestió oral i en uns altres casos d'introducció vaginal, destinats a expulsar el fetus. Tradicionalment aquestes fórmules pertanyien al saber femení, per bé que, sobretot a la baixa edat mitjana, també hi destaquen diferents metges, formats en Estudis Generals, que coneixen fórmules avortives. Tanmateix, era força usual colpejar la dona per a provocar l'expulsió del fetus com si fos fruit d'una caiguda accidental. Era una pràctica que s'aplicava també en animals quan convenia -per exemple, consta en vaques ${ }^{42}-i$ que a vegades era substituïda per banys d'aigua molt calenta.

L'infanticidi era un altre recurs que permetia superar els dos principals inconvenients de l'avortament: el possible dany a la mare -en l'infanticidi sols s'elimina el nadó un cop ha sortit del cos de la mare- $\mathrm{i}$ la possibilitat de ser selectiu per raó del sexe. Aquest és el principal avantatge: tant a l'alta edat mitjana ${ }^{43}$ com a la baixa ${ }^{44}$, l'infantici s'aplica als nadons de sexe femení abans que als de sexe masculí. A la Catalunya del segle XIV, de cada sis cadàvers d'infants trobats morts, cinc són nenes i només un és barón ${ }^{45}$. De fet, si la noia ja podia ser entesa com una càrrega a l'alta edat mitjana, molt més greu és a la baixa, quan ha perdut reconeixement social i no sols cal mantenir-la sinó fins i tot dotar-la

${ }^{41}$ E. A. WRIGLEY, Historia y población, Barcelona, 1985, pàg. 125.

42 Joëlle FuHRMANN, Les différentes causes, formes et fonctions du rire dans les mären de l'Allemegne du Moyen-Age tardif, "Le rire au Moyen Age dans la litterature et dans les arts", Bordeux, 1990, p. 187.

43 Emily Coleman, Infanticide in the Early Middle Ages, "Women in Medieval Society", S. M. StuARD, ed., Philadelphia, 1976, pp. 47-70.

${ }^{44}$ R. C. TReXler, Infanticide in Florence. New Sources and First Results, "The History of Childhood Quartely", 1 (1974), pp. 98-116.

${ }^{45}$ Flocel SABATE, Femmes et violence dans la Catalogne du XIVème siecle "Annales du Midi» (en premsa). 
quan arribi a l'edat núbil. La manera de portar els embarassos en aquella època -és freqüent arribar fins al final del període de gestació sense ferne ostentació $i$ amb poques evidències de l'estat - facilitava els equívocs i el mateix infanticidi ${ }^{46}$. Aquest configura una pràctica plenament femenina. Normalment, l'home sols hi intervé o com a encobridor o, un cop comès i descobert l'infanticidi, com a autoritat moral o civil que ha de reconduir la situaciós ${ }^{47}$. La preocupació per la mort d'un infant sense haver estat batejat $i$, en segon lloc, per haver estat en la majoria dels casos enterrat d'amagat fora de terra sagrada, afegeix, sobretot a la baixa edat mitjana, connotacions de gravetat a la pràctica, tal i com és reflectit en l'ànim i les actuacions dels clergues que hi intervenen en descobrir-se el cas, sovint arran de confessions penedides ${ }^{48}$.

Infantar el nadó i rebutjar-lo sense matar-lo configura un dels exercicis que s'allarga des de la societat romana precedent i que a la baixa edat mitjana es reiterarà força, sobretot amb l'augment de la pobresa al món urbà. El gruix principal d'aquests nadons abandonats procedeix de famílies pobres, però també s'hi compten els fruits de relacions establertes al marge del marc matrimonial, afectant molt sovint serventes a les urbs baix-medievals $i$, en menor nombre, membres dels més diversos grups socials, com és el cas d'algunes religioses ${ }^{49}$. A la baixa edat mitjana, les institucions de caritat han d'especialitzar-se en hospicis per tal d'acollir el gran nombre d'infants abandonats. Entre els recollits, molts pocs arriben a adults, atès que conformen el grup de nens amb un índex més elevat de mortalitat infantil.

Totes aquestes situacions, derivades algunes vegades de l'absència $i$, en unes altres de ben freqüents, del mal ús del matrimoni, segons la concepció imperant, perfilen una realitat diferent a la proclamada com a correcta. Ara bé, el matrimoni viscut no tan sols planteja problemes de cara al compliment de la seva finalitat procreadora. L'ordenament del matrimoni segons els cànons eclesiàstics entorn del segle XI permet, precisament, controlar un dels aspectes on l'Església palesava més preocupació: l'exogàmia. Durant l'alta edat mitjana l'Església tracta d'ampliar al màxim possible el grau de consanguinitat en el qual no sigui possible establir relacions. En el segle XII es valora fins al sisè grau ${ }^{50}$, consideració que serà rebaixada en l'important

46 AVV, Processos Criminals, lligall 2, sense numerar.

47 Cal matisar, per tant, la convicció que l'infanticidi medieval és una imposició masculina sobreposada al dolor de la mare (Milagros RIVERA, Textos y espacios de mujeres, Barcelona, 1990, pp. 149-158).

48 Flocel SABATE, Femmes et violence...

49 Maria Teresa VINYOLes, La condicio social de les dones a la Catalunya de la Baixa Edat Mitjana, "Perspectiva Social", 26 (1988), p. 29.

so Christopher BroOKe, The medieval Idea of Marriage, Oxford-New York, 1991, pp. 58-59. 
IV concili laterà, celebrat el 1215 , on la conjuntura d'un matrimoni molt més establert $i$ controlat permet reconduir cap a un quart grau, mesura en què resta practicament fixat ${ }^{31}$.

L'incest pot produir-se per un contacte més o menys esporàdic o com a establiment d'una relació estable i fixa, molt sovint matrimonial, entre parents propers que solen ser cosins. El primer cas és ben popular a l'alta edat mitjana, on es reiteren, acusats de pràctiques incestuoses diferents parents pròxims - cunyats, cunyades, pares, fills, mares, germans, cosinsque mantenen relacions sexuals més o menys esporàdiques amb gran facilitat en el context d'unes unitats familiars molt àmplies que fan vida en un espai comú molt reduït. El matrimoni entre cosins és, per la seva part, molt present entre els grups aristocràtics coetanis, per raó dels lligams que constantment calia establir. A la baixa edat mitjana esdevenen ben rars els contactes sexuals esporàdics entre parents pròxims $i$, en canvi, són freqüents les unions estables entre parents consanguinis, a vegades amagades rera matrimonis secrets. Al llarg de tota l'edat mitjana, les principals raons d'aquest incest eren, per una banda, la dificultat, sobretot en determinats medis rurals, de complir l'exogàmia que requerien els plantejaments eclesiàstics $i$, per altra banda, les necessitats d'acords entre grups socials mitjançant aquestes unions matrimonials. L'incest, més enllà de la consideració moral, pot ser interpretat en funció del trastorn social que pot generar. Vist així, no estranya la intromissió dels tribunals ordinaris, com és usual a la baixa edat mitjana, tot proporcionant ingressos als governants per les penes pecuniàries imposades als units en grau de consaguinitat ${ }^{52}$. A la vegada, l'Església tampoc no hi deixa d'intervenir i hi sol aplicar l'excomunió. Les dispenses eclesiàstiques concretes poden, però, atorgar validesa a la situació, la qual cosa contribueix a desfigurar la prohibició, per alguns entesa com una excusa per a obtenir guanys, tant per part del rei com per part de l'Església. Un exemple significatiu i elevat de la situació l'exposa el primer comte de Prades, l'infant Ramon Berenguer, el qual, el 1328, es casa sota dispensa amb una cosina en segon grau i, en enviudar, es torna a casar, el 1338 , ara amb una cosina en tercer grau i, com que no en demana dispensa, és excomunicat. L'any següent, l'arquebisbe de Tarragona li aixeca la pena com a comissari especial del papa Benet XVI mitjançant una dispensa degudament satisfeta pel comte i que valida el matrimoni ${ }^{53}$.

Molt més greu és establir ja no matrimoni sinó una relació sexual amb membres d'altres grups ètnico-religiosos. A l'alta edat mitjana, la progres-

s1 Christiane KLAPISH-Zuber, La mujer y la familia, "El hombre medieval", Madrid, 1990, p. 301.

52 ACA, Reial Patrimoni, Mestre Racional, 1566, fols. 2r, 4r, entre d'altres exemples.

s3 ADM, Sección Prades, legajo 1, núm. 4. 
siva incorporació dels diferents pobles germànics al catolicisme esborra l'impediment d'unió per motiu religiós alhora que reflecteix la unificació de la societat en una mateixa línia. Després d'aquests moments i de la fricció religiosa de caire herètic en els primers segles baix-medievals, els darrers segles de l'edat mitjana radicalitzaran la barrera sexual per motius ètnicoreligiosos. El caire sacramental del matrimoni i la creixent intolerància de la vivència popular del Cristianisme baix-medieval -esdevinguda eix central d'una societat que afirmava, cada cop més, la pròpia identitat en el rebuig de la diferència- facilita una progressió que manté cada vegada més separades les respectives comunitats, la cristiana i la jueva i, a la Península Ibèrica, la musulmana. L'error religiós d'aquestes comunitats n'era la justificació bàsica. En aquest context, era molt inusitat el contacte sexual amb jueus. Si de cas, es sol tractar de casos on un jueu ha pretès abusar d'una cristiana o extorsionar-la ${ }^{34}$. En canvi, les relacions entre cristianes i musulmans esdevenen un tòpic molt recorregut atès un suposat reclam dels musulmans, amb fama de ser, en general, atractius galants. A la Tortosa baix-medieval la conversa trivial i frívola més reiterada gira sovint entorn de quines dones s'hauran deixat seduir pels sarraïns, mentre que aquests bromegen també sobre les aptituds sexuals de les cristianes veïnes. Aquest clima fa que de vegades totes les dones detingudes a la presó de Tortosa hi siguin acusades de mantenir relacions sexuals amb musulmans. La pena a què s'enfronten és la mort, però gairebé totes se'n deslliuren per manca de proves.

La majoria d'aquestes dones, en cas de comprovar-se la relació sexual amb musulmans, afegirien molta gravetat a la seva falta en tractar-se de casos d'adulteri. En realitat, de tots els problemes que pot tenir una esposa medieval, sembla que cap no li pot ser tan perjudicial com ser sorpresa en adulteri. Durant tota l'edat mitjana l'adulteri de la dona és durament perseguit, pel fet de veure-hi perillar tant la continuitat i la puresa del llinatge com el mateix concepte matrimonial i l'ordre social. La condemna de l'adulteri comporta, també, un element de control i de superioritat de l'home sobre la dona, ja que la mesura no és aplicable, amb un rigor semblant, en sentit contrari. A més, atès el sentit de domini sobre les esposes viscut pels marits -sentiment agreujat a l'època baix-medieval- l'adulteri de la muller és viscut com un greuge, una injúria personal. Precisament, l'insult més comunament adreçat per les dones contra homes és el de cuguç o els seus equivalents banyut $\mathrm{i}$ cornut, al.lusius a la ignomínia d'haver estat víctimes de l'adulteri de l'esposass. És prou conegut que un dels mals usos (la cugucia)-normal-

54 Joseph Shatzmuler, Medecine et Justice en Provence Médievale. Documents de Manosque, 1262-1348, Aix-en-Provence, 1989, pp. 229-230.

ss Flocel Sabate, Femmes et violence... 
ment el tercer imposat pels senyors feudals als seus súbdits-exigeix greus exaccions als esposos de mullers adúlteres.

A l'alta edat mitjana el marit pot assassinar impunement la dona adúltera. A la baixa, no pot fer-ho legalment, però gairebé tots els assassinats d'esposes responen a l'adulteri d'ella o a la seva sospita. El gran problema de la justícia baix-medieval, en aquest aspecte, és fer entendre que aquesta pràctica és tipificada com a delicte, malgrat que socialment aquests uxoricidis configurin un comportament ben acceptat ${ }^{56}$. Francesc Eiximenis s'adreçarà vehementment als marits per tal que entenguin que no és aquesta la solució i que Deú fins i tot els pot castigar eternament ${ }^{57}$, mentre que, a Castella, Don Juan Manuel explicarà, en el conte d'un mercader que torna a casa després de vint anys d'absència per raons laborals, que abans de deixar-se endur per la ira cal assegurar-se'n bé, perquè, en l'assassinat de l'esposa sospitosa d'adulteri, el marit pot cometre una errada fatal ${ }^{58}$.

Moralment, l'adulteri és a vegades definit com una variant de la fornicació, entesa aquesta com el manteniment de relacions sexuals fora del marc del matrimoni. De fet, malgrat la prohibició moral i les penes clarament aplicades durant les visites pastorals baix-medievals ${ }^{59}$, mantenir relacions sexuals fora del matrimoni esdevé molt usual. Si el contacte respecta els marges imposats, és a dir, heterosexualitat, acoplament vaginal, unió no endogàmica $\mathrm{i}$ absència de relació amb col.lectius ètnico-religiosos diferents, la relació sexual s'entén normal i correcta i la seva materialització fora del matrimoni esdevé molt comprensiva i acceptada sobretot en els barons, que no estan sotmesos, a diferència de la dona, a l'exigència de la virginitat.

Contribueix a aquesta tolerància el raonament mèdic i ètic baix-medieval. Les relacions sexuals es plantegen com una necessitat social per a procrear la comunitat humana i, en funció d'això, són igualment enteses com una necessitat fisiologica humana: el cos de l'home genera constantment esperma, per la qual cosa cal extreure'l a temps per a deixar lloc a les noves fornades. Retenir el semen seria molt nociu per a la salut. Així, les relacions sexuals són una necessitat, sobretot per a l'home. En cas d'optar pel celibat, la natura mateixa ha de corregir l'excés d'esperma mitjançant les pol.lucions nocturnes. De tota manera, no sempre és suficient. En diferents ocasions els metges han entès que per a guarir el malalt cal forçar una ejaculació. Aquest plantejament pot comportar problemes morals, sobretot

36 AHMV, llibre de privilegis XXIV, pergamí 408.

57 Francesc EXIMENIs, Dotzè del Crestià, cap. DCXIIV, "Lo Crestià", Barcelona, 1983, pp. 229-231.

58 Don Junn MAnuel, El conde Lucanor, Madrid, 1982, pp. 203-205.

59 Pere Benito, Les parroquies del Maresme a la Baixa Edat Mitjana. Una aproximacio des de les Visites Pastorals (1305-1447), Mataró, 1992, pp. 209-210. 
per als clergues virtuosos. Es el que li succeí a l'arquebisbe de Lisboa, a mitjan segle XV, que, en desoir el consell mèdic i preferir mantenir les exigències de castedat, no es va guarir $i$ va morir ${ }^{60}$. La convicció que les relacions sexuals tenen una funció concreta i necessària en el funcionament del cos és ben popular i banalitzada. Francesc Eiximenis ridiculitza el clergue que ignora el vot de castedat amb l'excusa de la salut: per conservar sanitat, ús ab fembre sovint ${ }^{61}$.

Aquest clima d'acceptació de la relació sexual explica, en definitiva, el gran nombre d'actes sexuals practicats fora del matrimoni. Una de les conseqüències prou evidents consisteix en un nombre de fills il.legítims molt elevat, especialment a la baixa edat mitjana, essent aquesta filiació acceptada amb normalitat $i$, en el moment convenient, sobretot per raons d'herència, legitimada ${ }^{62}$. Són diferents les vies que porten a la relació sexual fora del matrimoni. Per una banda, s'hi arriba a partir dels sentiments d'atracció mútua. Tot i l'exigència de la virginitat, l'ideal amorós del segle XII i reiterat en la literatura posterior culmina en la fusió espiritual i física. De manera similar i més quotidiana, són coneguts molts casos, a la baixa edat mitjana, de joves que s'estimen plenament de manera espiritual i física. A més, el clima general era tan permissiu com escandalitzats n'estaven els predicadors. La realitat no amagava les relacions sexuals amb noies solteres. En aquest estat, se les podia entendre més lliures que no pas si fossin casades, estat en què la dona s'entén, de fet, propietat del marit. És el que deia un clergue que solia mantenir relacions sexuals amb dones: per tal que no faģa a negun injúria, faç-les me cercar fadrines ${ }^{63}$. Per això, hom ha pogut escriure que, en el període baix-medieval, entre el poble es parla de sexe sense massa miraments, $i$ és normal que una noia no sigui verge ${ }^{64}$.

De tota manera, l'exigència de virginitat prèvia al matrimoni es manté. D'aquí deriva l'èxit, sobretot a la baixa edat mitjana, dels ungüents $i$ altres fórmules per a refer l'himen perdut o, si més no, simular-lo. Com també en deriva el recurs a fórmules eròtiques que permetin compartir una plena satisfacció entre els dos amants sense posar en perill la virginitat física de la noia, tal i com ho expliquen diferents casos concrets tot assolint així, també, una pràctica contraceptiva.

En realitat, però, la gran majoria de les relacions sexuals alienes al 364.

${ }^{60}$ Jaime Villanueva, Memorias cronologicas de los Condes de Urgel, Balaguer, 1976, p.

${ }^{61}$ Francesc EIXIMEnis, Tery del Crestid, cap. CCCLIV, "Lo Crestia”, Barcelona, 1983, p. 143.

62 Jaume RIERA i SANS, Fills il.legitims a les darreries del segle XIV (inèdit).

${ }^{63}$ Francesc Exumenis, Ters del Crestià, cap. CCCIIV, "Lo Crestià", Barcelona, 1983, p. 143.

64 Teresa-Maria ViNYOLES, La violencia marginal a les ciutats medievals. Exemples a la Barcelona dels volts de l'any 1400, "Revista d'Història Medieval", 1 (1990), p. 169. 
matrimoni no deriven pas d'amors compartits sinó del desig sexual entès com a concupiscència. Aquest desig, que inflama l'home bàsicament per culpa de la luxúria pròpia de la dona, es combina amb la naturalitat fisiològica de la relació sexual. Així, en la població masculina, es practiquen relacions sexuals des de molt d'hora. Tots els predicadors concorden en la gran extensib de la fornicació entre els joves. Sant Vicenç Ferrer indica que tots els homes ja han conegut la carn femenina cap a l'edat de quinze anys. Aquesta gran i usual extensió de les relacions sexuals contribueix a dotarles d'un caire de naturalitat. En coherència amb aquesta naturalitat, molta gent no entén que aquesta relació sigui un pecat, tal com ho constaten clergues tant de l'alta com de la baixa edat mitjana. En plena coincidència, els mateixos eclesiàstics no atorguen gaire importància al fet, en si mateix, de mantenir, els homes, relacions sexuals fora del matrimoni. La majoria ho entenen com un pecat menor, i alguns dubten de llur pecaminositat ${ }^{65}$, sobretot si la relació s'ha realitzat en l'esmentada normalitat i sense cap més defecte que la manca de l'embolcall matrimonial.

D'un altre caire seria obtenir aquesta relació mitjançant la força. Imposar la relació sobre una dona reflecteix la superioritat de l'home. Però també pot indicar la superioritat d'una col-lectivitat que s'imposa sobre un altre grup, palesant-ho en l'agressió a allo que els vençuts guarden com a exponent de la puresa del llinatge o per la mateixa noció de castedad. Així, les invasions dels pobles nòrdics, dels pobles de l'est i dels musulmans del sud comporten sistemàtiques violacions en grup, de les quals foren remembrades víctimes les comunitats de religioses.

La imposició de la força en la relació sexual també pot esdevenir distintiu de la superioritat del grup social. En aquest sentit, les aventures cavalleresques comporten, per part del cavaller, l'obtenció del plaer sexual, si cal, imposant-1066. Sobretot, era ben entès que fossin coaccionades les noies de baix estrat social que s'hi resistien ${ }^{67}$.

La violació individualitzada, desproveïda d'aquestes connotacions és, alhora, present al llarg de tot el període. Serà objecte d'importants condemnes morals $i$ civils a l'alta edat mitjana, mentre que a la baixa manté una important presència. A la Catalunya del segle XIV, el $16 \%$ de les vegades en què les dones són víctimes d'actes violents es tracta de violacions, la qual cosa equival al 2 ' $5 \%$ de tots els crims comesos. I encara cal afegir-hi

65 Jeffrey RICHARD, Sex, dissidence and damnation. Minority Groups in the Middle Ages, London - New York, 1990, p. 38.

66 Concha María Ventura CResPo, Las lides amorosas, "Los caballeros medievales", Madrid, 1985, p. 19.

67 Marie WeRner, Tu sola entre las mujeres. El mito y el culto de la Virgen Maria, Madrid, 1991, pp. 192-193. 
els raptes que es perpetren amb la mateixa finalitat, que corresponen al $2 \%$ del conjunt de delictes violents amb dones implicades ${ }^{68}$.

Hom raonava que aquesta violència seria molt pitjor si no hi hagués una via de canalització del desig sexual que no pot ser encabit en el matrimoni. Aquest és l'espai de la prostitució. La prostitució és interpretada per tots els moralistes medievals com un mal menor necessari. Segons un sil.logisme atribuiit al pensament agustinià ${ }^{69}$, la prostitució és a la societat el que les clavegueres són als palaus: són immundes, però hi han de ser perquè, si no hi fossin, el palau s'ompliria de brutícia. Així, la prostitució té la funció de deslliurar la societat de les diferents violències sexuals que es podrien cometre si els usuaris no poguessin canalitzar els seus desigs.

La prostitució presenta una continuitat des de la societat romana precedent. Es, durant tota l'època medieval, present en les col-lectivitats masculines: acompanya els exèrcits cap les Croades i s'acomoda entre els estudiants dels Estudis Generals. De fet, l'edat mitjana central viu un increment molt fort de la prostitució, tot acompanyant el desenvolupament de les viles i ciutats. A París el $3 \%$ de la població baix-medieval és constituiit pel col-lectiu de prostitutes, xifra que es redueix a la meitat en poblacions mitjanes. Els poders públics controlen i regulen els espais de prostitució, tot delimitant unes zones a cada vila mitjanament significativa i tenint cura que no es practiqui fora d'aquest àmbit. Aquest exercici de control comporta guanys significatius per als governants. A la vegada, els monarques hauran d'intervenir-hi per protegir les prostitutes de les extorsions dels alcavots i dels hostalers, que solen ser els que més s'aprofiten de la seva activitat, a vegades amb contractes clarament abusius. El bordell, però, esdevé una zona molt conflictiva. A tot arreu és allà on es cometen més crims, especialment baralles físiques i robatoris. És més: a la Catalunya del segle XIV, del total dels actes de violència amb intervenció d'alguna dona, el $8 \%$ inclouen la presència d'una prostituta. El $15 \%$ d'aquests casos són prostitutes agredides per homes. La tensió del barri no exclou reiteratives tibantors entre les prostitutes: el $60 \%$ d'aquestes baralles són enfrontaments físics entre elles mateixes ${ }^{70}$.

Tant el creixement de la prostitució com aquestes característiques que l'aproximen a la marginació mouen alguns clergues a pressionar els poders públics per tal que regulin millor el fenomen o que el limitin, tot i que sempre es valora la seva funció profilàctica en el conjunt social. En qualsevol cas, no són mai mal vistos els usuaris de la prostitució, majoritàriament

68 Flocel SABATE, Femmes et violence...

${ }^{69}$ Leah Lydia OTIS, Prostitution in Medieval Society. The History of an Urban Institution in Languedoc, Chicago-London, 1983, p. 12.

70 Flocel SABATE, Femmes et violence... 
joves solters i, en menor nombre, clergues. En canvi, sí que són molt mal considerades les prostitutes. En moltes poblacions rebran imposicions similars a les aplicades als altres grups impurs -com els jueus o els llebrososamb limitació de l'accés als llocs sagrats i, sobretot, de tocar el menjar dels mercats, a més d'obligacions de dur vestits distintius. De fet, les prostitutes procedeixen dels sectors marginals de la societat, els que manquen d'un grup protector en l'engranatge de les solidaritats municipals. No tan sols són pobres sinó, molt sovint, estrangeres no prou integrades. A Catalunya, al segle XIV, la majoria de les prostitutes procedeixen del regne de Castella, seguit, pel nombre, de les de Sicília, València i Mallorca.

Un fenomen molt diferent és el de la prostitució masculina. És present en diferents ciutats franceses $i$ centreuropees $i$, sobretot, italianes, on a una ciutat com Venècia, el segle XV, prostituts i prostitutes es disputen ostensiblement els clients ${ }^{71}$. La prostitució masculina, en general ben clandestina i marginal, ens introdueix dins el món de l'homosexualitat masculina, la pitjor de totes les desviacions del comportament sexual segons el raonament baix-medieval.

L'homosexualitat masculina és present al llarg de tota l'edat mitjana. L'esquema més freqüent recull, normalment, una diferència d'edat i, sovint, d'estatus social entre els dos amants, on domina el de major edat $i$ estatus. En alguns casos, es tracta de parelles fixes, combinació més freqüent entre clergues. Però, molt més correntment, es tracta d'homosexuals que satisfan el desig amb amants esporàdics. Normalment, els homosexuals laics són casats i desenvolupen una vida matrimonial d'aparença normal, incloent-hi la procreació de fills, com ho fa el comte d'Empúries a començament del segle XIV ${ }^{72}$.

L'homosexualitat masculina sempre ha estat rebutjada per l'Església. Els qui la practiquen reben dures penitències a l'Europa alt-medieval, en qualsevol de les seves expressions: la penetració anal, la masturbació, la masturbació mútua o la penetració femoral. En el segle XI, però, es recullen parers encara molt més greus contra l'homosexualitat, sobretot si s'expressa amb la penetració anal, com ho especifica Lleó IX. Tot i la presència força desinhibida de l'homosexualitat en el segle XII, la llavor del rebuig moral s'enfortirà. Els grans teòlegs del segle XIII insisteixen en què l'homosexualitat masculina és la pitjor de totes les formes contranaturals del sexe. Atesa la gravetat amb què s'interpreta la pràctica, els poders civils hi intervenen. En tots els casos es condemna els homosexuals a la pena capital aplicada de la manera més ominosa. Així es fa al regne de Jerusalem el 1120, i el segle

71 James CLEUGH, La vita sessuale nel medioevo, Milano, 1963, p. 179.

72 Joaquim MIRET Y SANS, Sempre han tingut bech les oques. Apuntacions per la bistoria de les costumes privades, I, Barcelona, 1905, pp. 47-57. 
següent es consoliden les intervencions del mateix caire a tots els regnes cristians. La recepció del Dret Romà confirma i estén la pena capital, tot constatant que ja Justinià havia decretat el pitjor càstig per als homosexuals $^{73}$. La rá d'aquesta radicalització no es deu, pròpiament i en contra del que es va repetint ${ }^{74}$, ni a la influència $\mathrm{i}$ al temor dels sarrains, ni a petges herètiques, ni al trasbals derivat dels canvis socio-econòmics i polítics coetanis, ni a la necessitat de repoblar l'Europa desfeta per les tensions desfermades en la crisi baix-medieval. Tots aquests factors, si més no, contribueixen a fonamentar l'actitud hostil, però sense ser-ne la causa. La radicalització de la condemna dels homosexuals no és més que una mera conseqüència de la definició teleològica de la sexualitat. Si es posa l'accent en la procreació com a raó de ser de la relació sexual, l'homosexualitat masculina és la mostra més pregona de desviació, no sols per la tendència errònia sinó per la pèrdua d'esperma que comporta. Aquesta valoració es popularitza i es radicalitza encara més per la intolerància religiosa que va prenent cos i que propiciarà, igualment, les persecucions dels jueus: cada vegada fa més basarda tolerar l'error i la desviació, perquè la ira de Déu, si es curulla, castigarà tothom. En aquest sentit, un pensador prou significatiu com Joan Gerson no es cansarà de repetir que les desgràcies que sacsegen l'Europa baix-medieval són un càstig diví contra uns cristians que toleren errors prou evidents $i$ aberrants com la sodomia.

Una alenada diferent la constitueix la Itàlia renaixentista, que el segle $\mathrm{XV}$, tot i la creixent imposició de mesures coercitives, es va omplint d'homosexuals, com és molt ostensible a Venècia i a Florència. En aquesta ciutat, els cercles intel-lectuals descobreixen una homosexualitat honorable i una pederàstia exaltada a través del contacte establert amb l'obra de Plató, mitjançant l'estudi, a la famosa Acadèmia creada per Cosme de Mèdici, de Diàlegs prou reveladors com el Banquet o el Fedre ${ }^{75}$.

Molt diferent és la valoració que mereix el lesbianisme. Consta al llarg de tota l'edat mitjana. Es rebutjat com a expressió de la concupiscència i la luxúria pròpies de la dona, però, en no provocar cap vessament incorrecte d'esperma, no s'endinsa en els greus viaranys de l'homosexualitat masculi-

${ }^{73}$ James A. Brundage, Law, Sex and Christian Society in Medieval Europe, ChicagoLondon, 1987, p. 121.

74 John BOSweLl, Christianity, Social Tolerance and Homosexwality. Gay People in Western Europe from the Beginning of the Christian Era to the Fourteenth Century, Chicago, 1980, pp. 269-302; R. I. MOORE, The formation of a persecuting society. Power and deviance in Wester Europe (950-1250), Oxford, 1990, pp. 91-94; Jeffrey RICHARDS, Sex, dissidence and damnation. Minority Groups in the Middle Ages, London-New York, 1990, pp. 148-149.

75 Florència $f u$ sotto questo aspetto la nuova Atena, segons podrà recollir, un parell de segles després, Montesquieu i reivindicar, després d'unes altres dues centúries, André Gide (André GIDE, Corydon, Milano, 1952, p. 176). 
na. La seva pràctica s'amotlla a l'evolució viscuda per la consideració de la dona. Per això, és constatable a l'alta edat mitjana i esdevé ben present a l'edat mitjana central ${ }^{76}$, deixant-ne prou indicis rera les mateixes novel-les de cavalleries o a les estances de gineceu $i$ als banys compartits, mentre que, en els darrers segles medievals, la pràctica passa amb una major discreció.

Moralment, de vegades la relació lesbiana és resumida com una masturbació femenina compartida. Amb propietat, la masturbació és també una pràctica no natural, en la mesura que desvia la finalitat inherent a l'ús sexual. De tota manera, rep una consideració diversa segons l'evolució cronològica $i$, en tots els casos, segons es tracti de masturbació masculina o femenina.

La masturbació masculina consta al llarg de tota l'edat mitjana, tant entre adolescents com entre adults, practicada tant amb estimulació manual com amb ajut d'uns rudimentaris estris de fusta perforada. Condemnada amb una certa duresa a l'alta edat mitjana, en els segles següents és vista amb molta tolerància. Molts clergues accepten la masturbació com a manera de prevenir la fornicació. En conseqüència, la pecaminositat que pugui tenir la pràctica esdevé molt diluïda. A la baixa edat mitjana, en canvi, s'experimenta una modificació molt radical i es situa la masturbació masculina entre els pecats mortals més greus. El vessament d'esperma que comporta en l'home aquesta pràctica sexual és la raó d'aquest canvi. La gran preocupació per la conducció de la semença per tal d'amotllar la pràctica sexual a la seva finalitat no pot fer menys que escandalitzar-se davant d'una mostra prou pregona de balafiament de la llavor de vida i, alhora, de trencament de la funció teleològica de la relació sexual.

En canvi, la masturbació femenina rep altres consideracions més comprensives. Es present durant tota l'edat mitjana, practicada tant per estimulació manual clitoriana com mitjançant olisbes, principalment de fusta. Hom interpreta la pràctica com un fruit de la luxúria femenina, per la qual cosa és moralment rebutjada com una desviació, per bé que escaparà de les greus condemnes baix-medievals en no afectar per a res la conducció de l'esperma. En realitat, la baixa edat mitjana serà força comprensiva amb la masturbació femenina. Les consideracions mèdiques baix-medievals aprecien que les vídues i les verges són especialment propenses a patir sufocació de matriu, malaltia que es descrivia com un desplaçament de la matriu i que provoca en la dona un neguit $i$ una tensió que s'ha vingut relacionant amb la histèria. Per a guarir-la, cal retornar la matriu al seu lloc $i$ això sols s'assoleix mitjançant el recurs a la masturbació que substitueixi les rela-

76 José Enrique RUIz DOMÉNEC, La mujer que mira (crónicas de la cultura cortés), Barcelona, 1986, p. 126. 


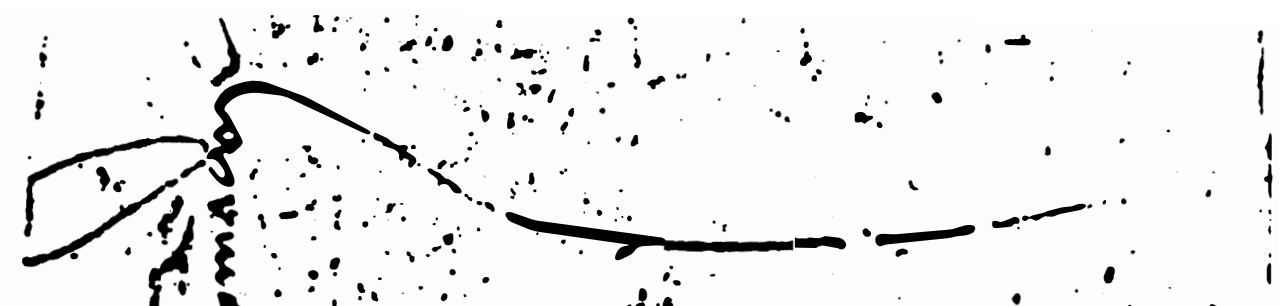

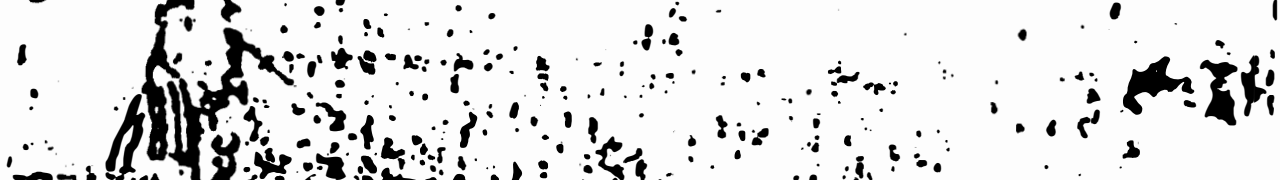

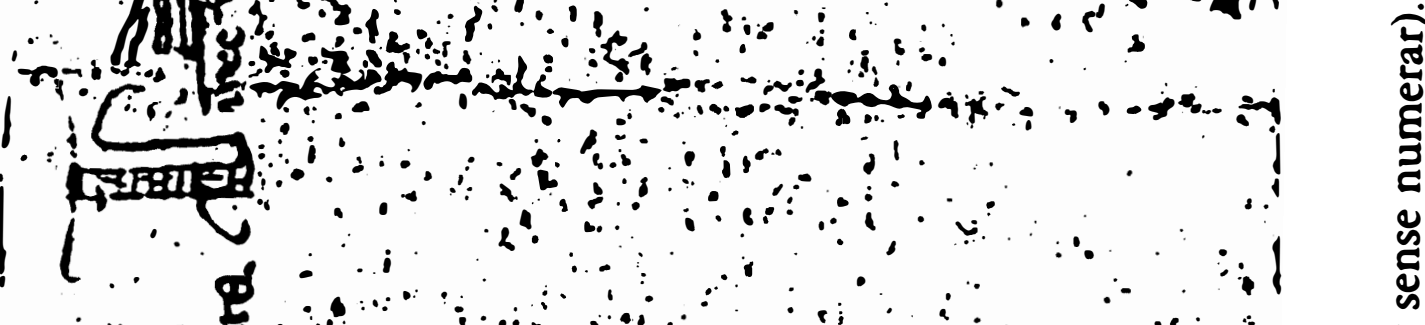

of

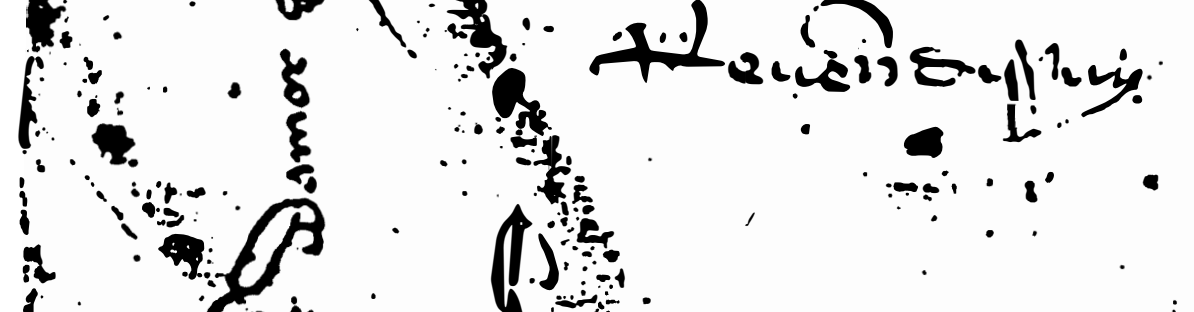

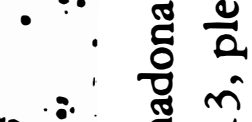
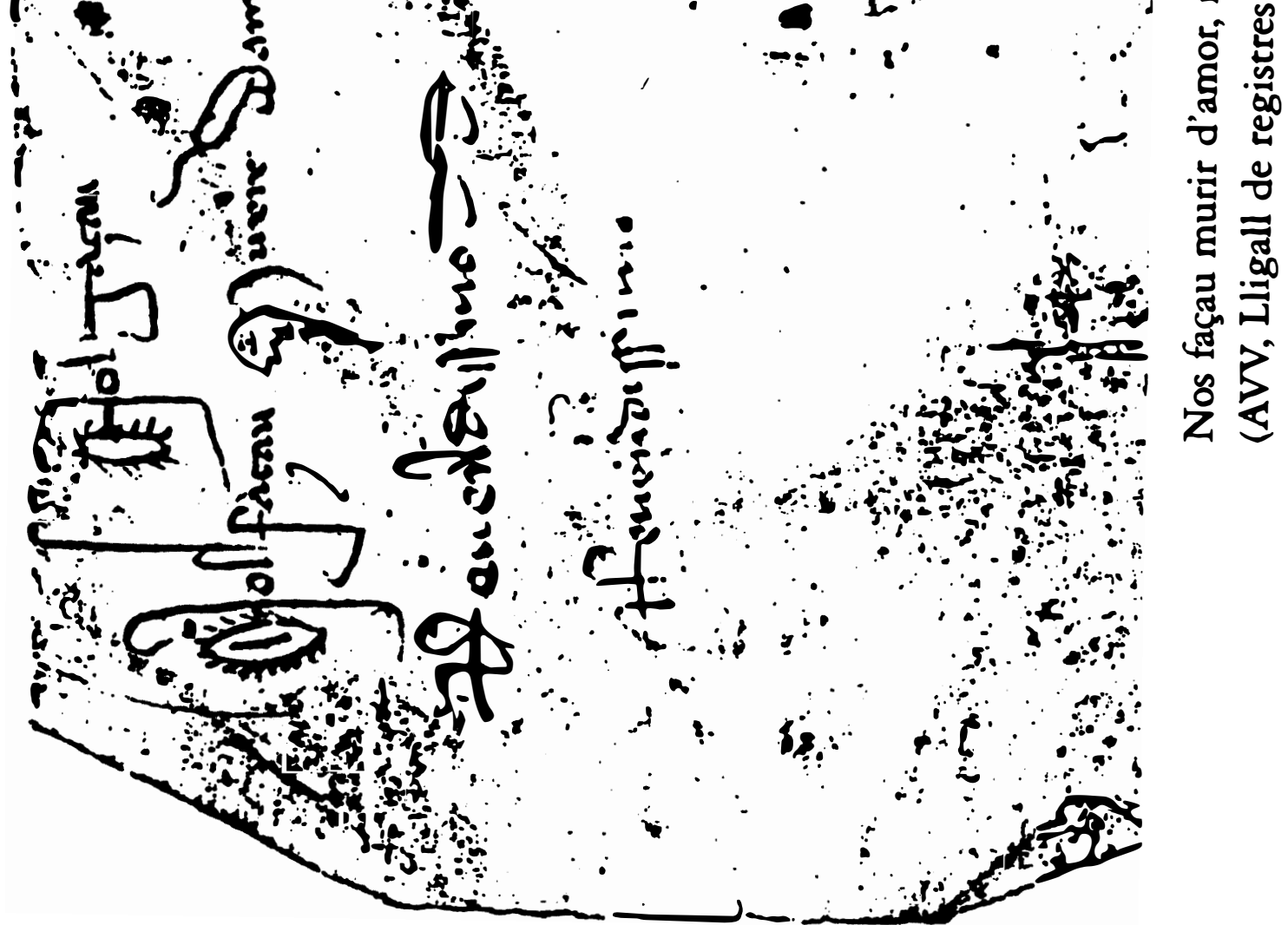
cions sexuals a les quals, per raó del seu estat social, aquestes dones no poden tenir accés. Acompanyar aquest guariment amb ungüents aromàtics és encertat i recomanable, tal i com ho coneixen les comadrones, les quals, si hom pot pagar els seus serveis, auxilien en el tractament regular de les sufocacions de matriu. Aparentment, aquesta pràctica pot comportar un conflicte entre salut i moral, ràpidament resolt, però, en diferenciar entre la mà que cura i la mà que taca. Aquesta porta al pecat perquè aplica l'autosatisfacció per un desig luxuriós. L'altra, en canvi, és bona i necessària perquè guareix una malaltia. De fet, hom va encerclant la masturbació en l'àmbit femení perquè la dona no té els recursos propis de l'home, a qui es permet un tracte sexual més desinhibit i ampli i a qui, a més, la natura el té dotat amb les pol-lucions nocturnes que regulen els conflictes físics de l'abstinència sexual. Per això, es ponderava, sobretot a la baixa edat mitjana, la masturbació com un fenomen més femení que no pas masculí.

Molt diferent, en canvi, és el recorregut efectuat per una altra de les pràctiques considerades antinaturals: el bestialisme. Mantenir relacions sexuals amb els animals és freqüent a l'alta edat mitjana. Es preferentment practicat per homes amb ovelles, vaques i someres, sobretot, i entre els practicants es situen molts pagesos i també clergues de tota la jerarquia eclesial $^{77}$. Entre les dones també existeix el fenomen, per bé que normalment la satisfacció s'obté sense recórrer a la penetració. La impuresa de l'acte, un cop descobert, obliga a sacriflcar l'animal afectat, sense que se'n pugui consumir la carn. Només les parts no comestibles -banyes i cuirsón aprofitables ${ }^{78}$. A la baixa edat mitjana el bestialisme és menys practicat, per bé que no és oblidat $i$ es condemna amb contundència dins d'una consideració sodomítica, coincidint amb el tractament coetàniament ofert per les legislacions vigents en aljames sarraïnes ${ }^{79}$. A la desviació seminal s'hi afegeix la valoració d'una important degradació de la condició humana $i$, per tant, de l'ordre natural, pel fet de rebaixar les funcions humanes a l'altura dels éssers irracionals.

En definitiva, la societat medieval defineix, en constant progressió, un estret marc propi i adient per a l'expressió sexual. Però, al costat d'aquesta pretensió, la mateixa societat aboca a altres pràctiques, difícils d'encabir en l'estructuració social imperant. Aquests recursos forcen l'atenció dels grups ideològics $i$, en alguns casos, faciliten una intervenció del poder polític, sempre des de la pretensió de classificar, endreçar i, si es considera necessa-

77 Pierre J. PAyer, Sex and the Penitentials. The Development of a Sexual Code (550-1150), Toronto, 1984, pp. 44-46.

78 Pierre BONNassie, Del esclavismo al feudalismo en Europa occidental, Barcelona, 1993, p. 79.

79 Llibre de la Çuna e Xara, Carmen BArCelo, ed., Córdoba, 1989, p. 23. 
ri, tractar de corregir o d'eradicar unes actituds $\mathrm{i}$ unes formes incorrectes que rebran diferents consideracions en una gradació adient del rebuig i de la condemna. L'afany d'aplicar els enquadraments i les definicions considerades correctes a vegades poden estrènyer força no sols l'expressió sinó la mateixa al.lusió al fenomen sexual. Com a resposta, s'obren les vies de la imaginació en l'expressió dels continguts de la sexualitat.

\section{LES VIES DE LA IMAGINACIÓ}

L'edat mitjana és incompleta sense la visió oferta per un món imaginari on s'acullen els arquetips de la vida quotidiana, les imatges de les sensacions $i$ dels sentiments difícils d'explicar $i$, en definitiva, la representació misteriosa i seductora de tot allò que atrau i de tot allò que es rebutja.

A la catedral de Moissac una dona lligada per serpents exposa uns genitals devorats per una granota. Es una imatge prou evocadora, per a tots els homes i dones de l'època, expressió dels perills que obre el sexe i de la proximitat del mal en la dona, des de la primera temptació de la serp. De fet, les imatges configuren tota una didàctica: els atributs que representen l'essència de la dona, una pinta i un mirall, són reiterats sistemàticament, $\mathrm{i}$ aquesta sola imatge, si cal reblada amb la representació de la luxuriosa humitat de les sirenes ${ }^{80}$, és suficient, en l'home medieval, per a entendre quina és l'essència constitutiva atribuiida a la dona, de la mateixa manera que, a nosaltres, la mateixa sola imatge basta per a transportar-nos quina és l'essència del pensament sexista medieval.

La iconografia, però, no és mai estable. La simbologia, sorgida de l'interior de les creences de la societat, evoluciona amb aquesta. La luxúria era un boc agressiu a l'alta edat mitjana, mentre que a la baixa és una cabra mai prou satisfeta ${ }^{81}$. Els dimonis representats amb atributs físics femenins al final de l'edat mitjana són, en aquest sentit, l'expressió més pregona de la desembocadura cap a on mena l'evolució seguida en la concepció de la dona.

Les arquivoltes esculpides $i$, sobretot, els permòdols i gàrgoles, on es representen els monstres i els vicis que cal no seguir, configuren un lloc adient per a representar la sexualitat prohibida i vedada, que cal conèixer per defugirla. Per això, un permòdol de la catedral de Beaujolais mostra una ostensible

80 Ignacio MalnXeverria, Animales y espejos, "Literatura y fantasía en la Edad Media", Granada, 1989, pp. 143-146.

${ }^{81}$ Mireille VINCENT-CASSY, Les animaux et les péchés capitaux: de la symbolique à l'emblematique, "Le monde animal et ses répresentations au Moyen Age. XI-XV siècles", Toulouse, 1985, p. 128. 
escena de bestialisme, amb una dona posseïda sexualment per un gros animal. A la vegada, aquestes mateixes representacions permeten recrear-s'hi i poder així al.ludir, amb les mateixes imatges, escenes que sols es poden expressar en l'ambigüitat de reflectir allò que potser atrau però que, en realitat, caldria defugir. Aquest és el lloc per a representar apassionades escenes d'una sexualitat no sempre ajustada a la normativa, com s'esdevé en les masturbacions mútues practicades per una parella representada a la col-legiata de Santillana del Mar. En altres casos la representació copsa escenes més convencionals, per bé que recreades en la penetració vaginal i els rostres expressius dels amants, com es reprodueix a l'escena de còpula en un permòdol de l'església de Sant Miguel de Fuentidueña (Segòvia). Aquest és també el lloc per a fer ostentació dels organs genitals, sia mostrant uns ostensibles genitals masculins, com és el cas de l'església de Sant Llorenç de Lleida, o imaginant uns fal.lus al.lusivament engrandits, com a Santillana del Mar. Es tracta no pas de recrear-se en la nuesa sinó en l'ostentació genital: un capitell de la catedral de Jaca, per exemple, mostra amb naturalitat la nuditat d'Isaac quan el seu pare el duia a l'ara del sacrifici, però, en canvi, a Banyuls de la Marenda, l'element genital d'una figura humana en una de les arquivoltes de la façana del temple romànic és prou realçat per si mateix. Ostentar el genitals femenins no és tan freqüent, però no falta, $i$ amb detall, en la representativa $i$ agosarada escultura d'un capitell molt evident de San Pedro de Cervatos (Cantàbria), tot i que és més freqüent expressar la sensualitat femenina amarada en els pits, com es representa a l'església de Sant Llorenç de Lleida. Significativament i sensualment, una imatge molt reiterada a la baixa edat mitjana és la captació de la masturbació femenina, com es veu a l'edifici de la Llotja de València o a l'església parroquial d'Ulldecona. Així, conjuminant l'obligació de representar allò que no està gaire bé amb la voluntat d'esbravar el desig d'ostentar la sexualitat, aquestes representacions, de vegades ubicades 'en llocs ben vistosos i evidents, més que no pas revoltar-se contra el sistema social ${ }^{82}$, obren una via d'expressió de la realitat i de la imaginació. D'aquesta manera, s'estableix una permissibilitat aparentment agosarada però, en realitat, força coincident amb la normalitat socialment admesa. Per això, les insinuacions i al.lusions eròtiques o les escenes heterosexuals aparenten una provocació, però, en canvi, el pecat nefand -la homosexualitat masculina- serà irrepresentable en la baixa edat mitjana que ha arraconat qualsevol possible tolerància ${ }^{83}$.

En definitiva, mitjançant aquestes formes prou gràfiques, es pot expres-

${ }^{82}$ Com insisteixen versions des de la divulgació. Vegeu, per exemple: Rafael ALARCón HeRrerA, Enigmas del tantra cristiano, "Año Cero", III-21 (1992), pp. 58-63.

${ }^{83}$ Certament, les representacions artístiques de l'homosexualitat masculina difícilment es reiteren més enllà del segle XII (John BosWell, Christianity, Social Tolerance, and Homosexuality. Gay People in Western Europe from the beginning of the Christian Era to Fourteenth Century, Chicago-London, 1980, llàmines sense numerar). 
sar allò que costa de dir, tot i que se'n vol parlar. De manera similar, també es pretén amagar el sentit sexual rera uns altres termes i vocables. Són els jocs de paraules $i$ els acudits, que no sols tracten d'encetar una hilaritat ${ }^{84}$ sinó que intenten donar la volta a la societat i poder parlar d'allò de què no es pot parlar ${ }^{85}$ o de què, en qualsevol cas, no es pot parlar palesant-ne satisfacció. I, si és possible, a vegades es tracta d'emprar el discurs apropiat per a parlar d'allò més sagrat tot volent, en realitat, expressar allò més carnal ${ }^{86}$. En el fons, el mateix llenguatge reflecteix, d'aquesta manera, les paradoxes d'una societat amb uns desigs no ben bé concordants amb els models assumits.

Tot això succeeix al costat d'un món paral.lel poblat de dames i donzelles que penetren en el món humà per encisar cavallers, o viceversa, de cavallers fadats que fan el mateix amb dones belles i nobles ${ }^{87}$. Tanmateix, si això té lloc en un context de cavallers i donzelles voltats d'amor cortès, el darrer segle medieval l'àmbit real troba preferència pel món imaginari menys ordenat, amb salvatges folls d'amor que també envaeixen el món real però provinents de boscos encara evocadors i conduïts, tan sols, pels sentiments més espontanis $i$, a la vegada, més amorosos ${ }^{88}$. En realitat, la sensació de trobar-se sumit en una normalitat no prou justa ni satisfactòria fa cercar els moments imaginatius i lúdics per a tractar de trastocar els papers, com fan les dones que, aprofitant el carnestoltes, es disfressen d'homes $^{89}$ o assumeixen el paper directiu que la societat reserva a l'home, tant en aspectes formals -el ball- com en actituds combatives ${ }^{90}$, just enfront d'una societat que arracona la dona fins al punt d'haver d'adoptar l'home la mateixa feminitat imprescindible en representacions teatrals o en d'altres formulacions lúdiques ${ }^{91}$.

${ }^{84}$ BRUNO ROY, L'bumour frotique au XVe siecle, "L'erotisme au Moyen Age. Troisième colloque de l"Institut d'études médiévales de l'Université de Montréal», Québec, 1977, p. 156.

8s Thérése Bouche, L'obscene et le sacré a l'utilisation paradoxale du rire dans le roman de la Rose de Jean de Meun, "Le rire au Moyen Age dans la litterature et dans les arts", Bordeux, 1990 , p. 80.

${ }^{86}$ Carmen Escudero, Ironie et ambiguite dans le Libro de Buen Amor, "Le rire au Moyen Age dans la litterature et dans les arts", Bordeaux, 1990, p. 198.

87 Isabel de RIQUER, El cavaller fadat, "L'Avenç", 107 (1987), p. 176.

88 Jacques Heers, Carnavales y fiestas de locos, Barcelona, 1988, p. 220.

89 Susan STUARD, The Domination of gender. Women's fortunes in the bight middle ages, "Becoming visible women in european history", Boston, 1987.

90 Marjoke DE ROOS, Misogynie et matriarcat: le role de la femme dans les jeux de carnaval (XVe-XVle siżles), "Actes du 115 è Congrès National des Societés Savantes, Théatre et spectacles hier et aujourd'hui. Moyen Age et Renaissance (Avignon 1990)", Paris, 1991, p. 214.

91 M. GRINGERG, Hommes sauvages, cornards et travestis: femmes absentes?, "Actes des premières rencontres internationales. Le carnaval, la fête et la communication" (Nice, 1984), Nice, 1985, p. 282. 
En qualsevol cas, sempre resta el recurs de la imaginació personal i íntima. A Vic, a mitjan segle XIV, l'escrivà de la cort vicarial, mentre li era dictada una carta adreçada a una alta jerarquia eclesiàstica, entretenia el pensament remembrant, tant espiritualment com físicament, l'estimada que el feia morir d'amor, estampant, a la vegada, uns espontanis dibuixos eròtics sobre el paper ${ }^{22}$ que l'obligaren a començar de nou la lletra i a deixar el paper estampat, amb els requeriments i les al-lusions a l'estimada i amb les expressions genitals d'ambdós, per als historiadors que, seguint-li el pas, tractem d'escorcollar la mentalitat dels qui ens han precedit per tal de conèixer-nos una mica millor.

\section{RÉSUMÉ}

Parcourir l'expression de la sexualité humaine tout au long du Moyen-Age a permis d'y apporter de nouvelles interprétations. A la méfiance envers le sexe, état de pensée propre au Haut Moyen-Age, succède le Bas Moyen-Age, époque qui accepte la sexualité comme une fonction nécessaire pour la procréation, influencée en cela par la médecine arabe, la physique aristotélicienne et les exposés philosophiques et théologiques dérivés d'abord de la scholastique et, plus tard, du nominalisme. Une vision théologique de la fonction sexuelle s'impose: elle est considérée bonne si elle s'applique dans l'unique fin de procréer. De là dérive une obsession pour la conduite (l'utilisation) du sperme. Sont considérées comme correctes les expressions sexuelles qui garantissent son passage du corps de l'homme vers celui de la femme, où il devra germer. L'utilisation de la sexualité qui n'a pas cette finalité est considérée contre nature, en commençant par l'homosexualité masculine et en y incluant toutes les formes qui gaspillent le sperme (masturbation masculine, bestialité). Les relations sexuelles considérées comme normales se définissent par l'hétérosexualité exogame, qui n'a pas de rapport avec des groupes ethno-religieux différents et utilisant, uniquement, la pénétration vaginale. Cette relation doit se dérouler dans le cadre d'un mariage chrétien à la manière dont il s'est imposé au milieu du Moyen-Age. On réserve toujours les parcelles dominantes à l'homme et les domestiques à la femme. Elle perd progressivement de la considération au Bas Moyen-Age, poussée tant au niveau de la féodalité que des groupes urbains, par l'agnation sur le premier né masculin et par le discours intellectuel contraire.

\section{SUMMARY}

New interpretations were brought forward by going again over the expression of human sexuality during the Middle Ages. While the high Middle Ages is

92 AVV, Lligall de registres 13, plec 1344-1345, full solt sense numerar. 
characterised by mistrust in front of sexe, low Middle Ages accepts sexuality as a necessary function for procreation, probably influenced by arab medicine, by Aristotle's physics and by philosophic and theologic statements derived from scholasticism and, afterwards, nominalism. A theleological vision of sexual function imposes itself: it is considered as good if it fits its only purpose, procreation. From this idea derives an obsession about the conduction of the sperm. Sexual expressions that garantee the sperm transfert from the body of the man to that of the woman, where it will germinate, are correct. Different sexual habbits are considered against nature, starting from male homosexuality and including all the ways that waste the semen (male masturbation, use of animals, etc.). Sexual relations considered as normal have in common to be heterosexual and exogamous, to be alien to deals with different ethnico-religious groups and to use exclusively vaginal penetration. This relation has to find place within christian marriage, as it has been stipulated and imposed since halfway through the Middle Ages. Dominant roles are attributed to man while woman takes care of domestic tasks. The way to consider woman begins to degradate during low Middle Ages, from both rural areas of feudalism and urban groups, by agnation on the male firstborn and through a contrary intellectual speech. 